\title{
Habitat Use by Brood-Rearing Waterfowl in Subarctic Québec
}

\author{
ROBERT DÉCARIE, ${ }^{1}$ FRANÇOIS MORNEAU, ${ }^{1}$ DANIEL LAMBERT, ${ }^{1}$ \\ SUZANNE CARRIÈRE ${ }^{2}$ and JEAN-PIERRE L. SAVARD ${ }^{3}$
}

(Received 20 October 1993; accepted in revised form 17 August 1995)

\begin{abstract}
Aerial surveys of waterfowl were conducted in subarctic Québec in 1989 and 1990 on randomly selected $100 \mathrm{~km}^{2}$ plots. We used logistic regression for modelling relationships between the presence of waterfowl broods and habitat characteristics. For each species, models of habitat use were generated with one data set and tested with two others. We also compared the frequency distributions of broods of each species in different habitat types. Correct-classification rates of models varied between 0.53 and 0.77 . Sensitivity of models generally increased when applied to validation data sets. Models showed that green-winged teals (Anas crecca) avoided lakes $>501$ ha and used vegetated lakes, ponds and fens or bogs more than predicted by their availability. Black scoters (Melanitta nigra) and surf scoters (M. perspicillata) were found mostly on small lakes $(<10$ ha) and medium lakes (10-100 ha). Black scoters were associated with the presence of ponds and lakes with sedge and grass, whereas surf scoters were not. The presence of scaup (Aythia spp.) broods was associated with the presence of vegetation. Green-winged teals were observed more often on bogs than were either scoters or scaups. Black scoters were observed more often on ponds and less often on medium-sized lakes than surf scoters and scaups. The latter differed in their use of lakes $<10$ ha: surf scoters, like black scoters, mostly used unvegetated lakes, while scaups and green-winged teals mostly used vegetated lakes. The accuracy and precision of logistic models may be enhanced by additional habitat variables, careful selection of sample-cell size and further investigation of the breeding biology of the surveyed species.
\end{abstract}

Key words: habitat, model, logistic regression, northern Québec, black scoter, surf scoter, green-winged teal, scaup, brood

RÉSUMÉ. Des inventaires aériens de sauvagine dans des parcelles de $100 \mathrm{~km}^{2}$ sélectionnées aléatoirement ont été réalisés dans le Québec subarctique en 1989 et en 1990. La régression logistique fut utilisée pour modéliser les relations entre la présence de couvées et des paramètres d'habitat. Des modèles d'utilisation d'habitat ont été générés à l'aide d'une série de données et validés à l'aide de deux autres. Nous avons aussi comparé les distributions de fréquences des couvées des espèces étudiées dans divers types de biotopes. Les taux de classification correcte des modèles ont varié entre 0.53 et 0.77 . De façon générale, la sensibilité des modèles augmentait lorsque ces derniers étaient appliqués aux données de validation. Les modèles montrent que la Sarcelle à ailes vertes (Anas crecca) a utilisé les plans d'eau avec de la végétation, les étangs et les tourbières et a évité les lacs $>501$ ha. Les macreuses (Melanitta nigra, M. perspicillata) ont surtout été vues sur des lacs de petite ( $<10$ ha) et moyenne (10-100 ha) superficies. Les Macreuses à bec jaune se démarquaient des Macreuses à front blanc en étant associées à la présence d'étangs et de lacs avec des herbaçaies. La présence de couvées de morillons (Aythia spp.) dans les cellules était associée à celle de végétation. La Sarcelle à ailes vertes fut observée plus souvent dans les tourbières que les autres espèces. La Macreuse à bec jaune fut observée plus souvent sur des étangs et moins souvent sur des lacs de superficie moyenne que la Macreuse à front blanc et les morillons. Ces dernières espèces différaient dans leur utilisation de lacs $<10$ ha: les Macreuses à front blanc, comme les Macreuses à bec jaune, utilisaient surtout les lacs aux rives sans végétation alors que les morillons et les sarcelles utilisaient surtout des lacs avec végétation. La précision des modèles de régression logistique pourrait être augmentée par l'utilisation de paramètres d'habitat supplémentaires, un choix différent de la taille de l'unité de mesure et une meilleure connaissance de l'écologie des espèces cibles.

Mots clés: habitat, modèle, régression logistique, Québec, Macreuse à bec jaune, Macreuse à front blanc, Sarcelle à ailes vertes, Morillons, couvée

\section{INTRODUCTION}

Surveys of waterfowl in western North America (Martin et al., 1979; Reynolds, 1987) have permitted long-term studies of breeding habitat use (Johnson and Grier, 1988). In the Northeast, however, surveys have been sporadic (Gillespie and Wetmore, 1974; Goudie and Whitman, 1987; Savard and Lamothe, 1991) or limited to early breeding species such as the black duck (Anas rubripes) and Canada goose (Branta canadensis) (Kaczynski and Chamberlain, 1968; Bordage, 1988; Malecki and Trost, 1990). The boreal and subarctic region of Québec is characterized by low densities of breeding waterfowl (Bordage, 1988; Savard and Lamothe, 1991). However, the region is vast and may harbor significant proportions of the continental populations of black scoters (Melanitta nigra) and surf scoters (M. perspicillata), which

\footnotetext{
${ }^{1}$ Groupe de Recherche et d'Études en Biostatistique et en Environnement, 2045 Stanley, Montréal, Québec H3A 2V4, Canada

${ }^{2}$ Département de Biologie, Université Laval, Ste-Foy, Québec G1K 7P4, Canada

${ }^{3}$ Canadian Wildlife Service, 1141 route de l'Église, C.P. 10100, Ste-Foy, Québec G1V 4H5, Canada

(C) The Arctic Institute of North America
} 
are among the least-studied waterfowl of North America (Savard and Lamothe, 1991). These two species are currently experiencing increased pressure from hunting (Ad Hoc Sea Duck Committee, 1993) and hydroelectric developments (Savard and Lamothe, 1991).

The costs and logistics of working in this large area have precluded intensive waterfowl studies. Several portions of northern Québec remain unsurveyed, and habitat preferences are still unknown for many species. We conducted aerial surveys to investigate wetland use by broods of five of the most abundant species breeding in subarctic Québec: greenwinged teal (Anas crecca), black scoter, surf scoter, greater scaup (Aythya marila), and lesser scaup (A. affinis). We also evaluated the efficiency of logistic regression models to predict waterfowl presence or absence on the basis of macrohabitat characteristics.

\section{STUDY AREA}

The study area included the entire catchments of the Grande and Petite Baleine rivers, sections of the Nastapoka River basin, and the catchments of all the coastal rivers between the estuaries of the Grande and Petite Baleine rivers (Fig. 1). It covered $60300 \mathrm{~km}^{2}$ in two noncontiguous parcels between $54-58^{\circ} \mathrm{N}$ and $70-78^{\circ} \mathrm{W}$. Boreal forest covers twothirds of the study area. The rest consists of forest tundra, which is transitional between continuous boreal forest and arctic tundra (Payette, 1983) (Fig. 1). Arctic vegetation is found only on the summits of the cuestas which parallel the coast. Lakes and ponds often lack vegetation; many are partly bordered by sedge and grass and/or shrub strips. Patches of aquatic vegetation can be seen on some water bodies. The average density of water bodies per $100 \mathrm{~km}^{2}$ is 126 lakes ( $\left.<10 \mathrm{ha}\right)$, 17 lakes (10-100 ha), 3 lakes (> $100 \mathrm{ha})$, and 95 ponds.

\section{METHODS}

\section{Sampling Design}

As this work was part of an impact assessment study that included a comparison of different subregions of the study area, we used a stratified random sampling design (Cochran, 1977), dividing the study area into 12 strata based on areas affected by the hydroelectric project and on a control area (not

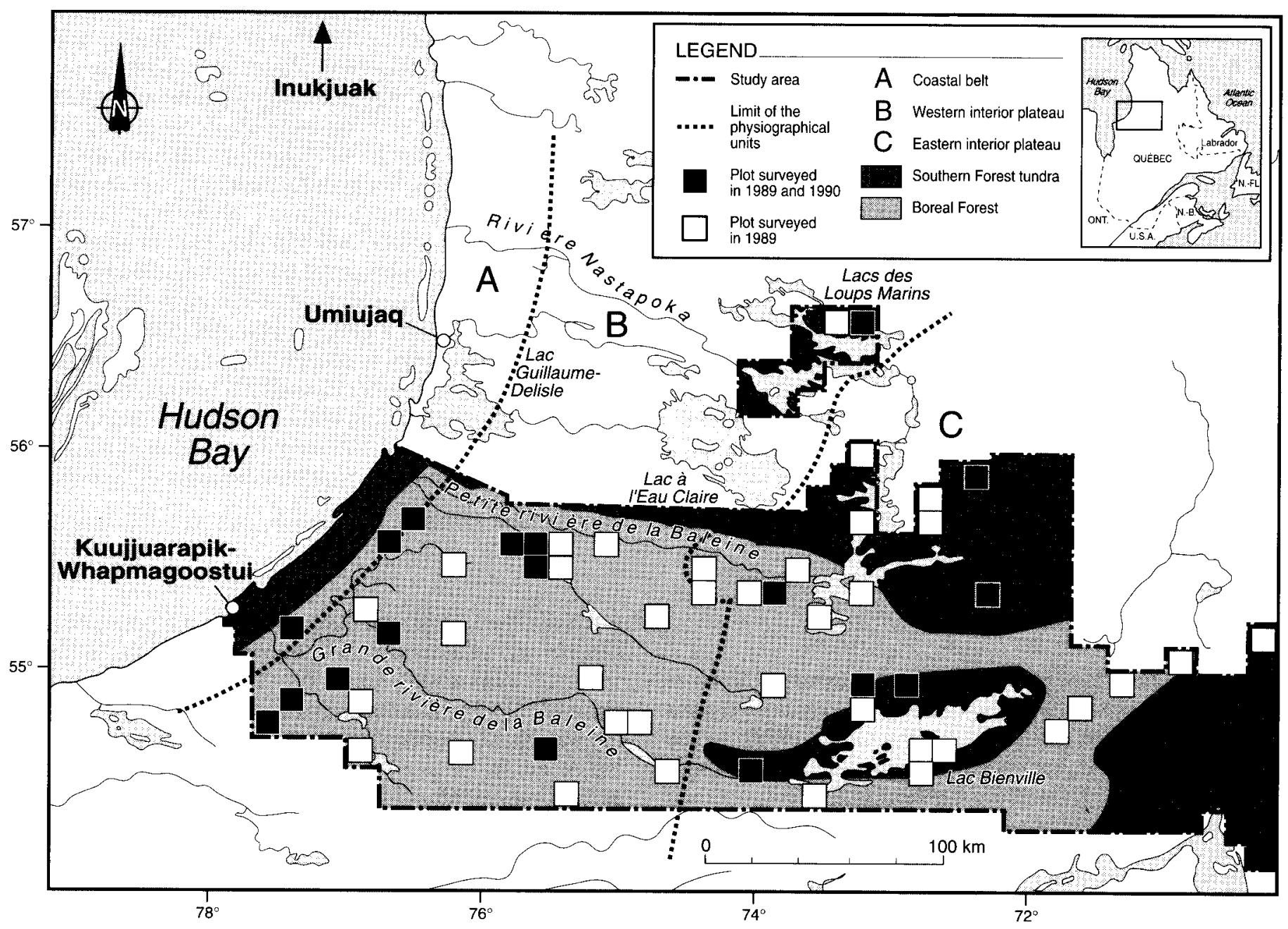

FIG. 1. Surveys of waterfowl in 1989 and 1990 in subarctic Québec: study area and surveyed plots. 
discussed here) (Consortium Gauthier \& Guillemette G.R.E.B.E., 1990). A map of the entire study area was covered by a $100 \mathrm{~km}^{2}(10 \times 10 \mathrm{~km})$ plot grid. A total of 603 plots formed the statistical population, from which 55 plots selected at random, covering $9.1 \%$ of the study area, were surveyed in 1989. In 1990, 18 of these 55 plots were resurveyed (Fig. 1). The 18 plots were selected to test the variability of waterfowl densities. Hence, they covered the range of abundances for all species, including those not reported here.

\section{Aerial Survey}

The census technique, adapted from Bordage (1988), consisted of a direct count of broods from a helicopter (A Star ${ }^{\mathrm{TM}}$ 350 with bubble side-windows and skids) in all wetlands of a $100 \mathrm{~km}^{2}$ plot. Flight speed and elevation varied from one wetland to another. Bogs were skimmed $(60-90 \mathrm{~km} / \mathrm{h})$ and lake and pond shores were flown over at an altitude of $10-20 \mathrm{~m}(90-110 \mathrm{~km} / \mathrm{h})$ to chase hidden waterfowl toward open water. A wetland could have been circled two or three times to make sure that broods were detected. Moreover, one or more transects were done over large lakes at a higher altitude $(>40 \mathrm{~m})$ and greater speed $(100-120 \mathrm{~km} / \mathrm{h})$ to cover the entire area. Streams and rivers were followed linearly, but when rivers widened, banks and island shores were overflown. We avoided flying on days with fog and winds over $30 \mathrm{~km} / \mathrm{h}$. The crew was a pilot and two observers: one in front, on the pilot's left, who navigated, observed and wrote down data; the other, behind the pilot, detected birds and identified species and age of broods. The three members communicated through interphones. Adult waterfowl with broods were noted on a 1:50 000 scale map of the plot. From a helicopter, identification of greater and lesser scaups relies on the coloration of six feathers on each wing (Bellrose, 1980). As most females were moulting during survey periods, it was not possible to identify broods; thus they were noted only as scaup.

\section{Green-winged teal $(n=95)$}

Black scoter $(n=55)$

Surf scoter $(n=28)$

Scaup spp. $(n=56)$

1989 Surveys

1990 Survey

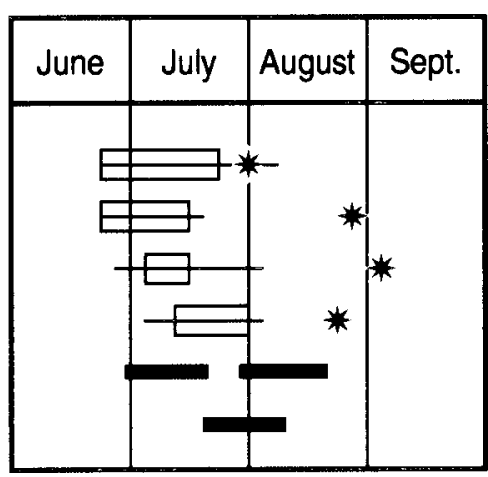

FIG. 2. Survey periods and hatching chronology of the species studied based on 1989 data $(\square=$ hatching period; $\square=$ peak; $*=$ beginning of flight stage $)$

We selected survey periods based on hatching dates of resident waterfowl (Bider and Lamothe, 1982). In 1989, we conducted two censuses of the 55 plots: from 29 June to 21 July and from 27 July to 21 August. In 1990, we conducted one census of 18 plots between 21 July and 10 August to overlap with the time period of the second census of 1989 when more broods were seen (Fig. 2). The large size of the study area, complex network of wetlands, and number of days when weather conditions precluded flying caused the lengthy period over which censuses were conducted.

Breeding chronology was estimated by backdating, using brood age, incubation and brooding durations. Only broods that could be aged precisely were used. Brood age was determined as the median of the range of days established for each of four brood age classes (Gollop and Marshall, 1954; Bellrose, 1980; Palmer, 1976 [for scoters]). Incubation and brooding periods were based on Bellrose (1980) and Palmer (1976).

\section{Habitat Description}

Each selected plot was divided into 100 cells of $1 \mathrm{~km}^{2}$ that were described using a set of habitat variables (Table 1). The number of ponds and lakes of different sizes and the length of rivers in each cell were quantified on 1:50 000 topographic scale maps. Ponds were defined as water bodies visible on 1:50 000 scale maps but isolated from other water bodies, whereas lakes $<10$ ha were linked to the watershed network. The variable "river" includes rivers and streams with both shores visible on 1:50 000 scale maps.

TABLE 1. Habitat variables measured in $1 \mathrm{~km}^{2}$ cells in 55 plots surveyed in subarctic Québec, 1989.

\begin{tabular}{ll}
\hline \hline Description & Code \\
\hline Variables measured on 1:50 000 topographic maps: & \\
& \\
Length of river banks $(\mathrm{km})^{1}$ & River \\
Number of ponds ${ }^{1}$ & Ponds \\
Number of lakes $<10$ ha & L $<10$ ha \\
Lakes 10-100 ha (p-a) ${ }^{3}$ & L 10-100 ha \\
Lakes 101-500 ha (p-a) & L 101-500 ha \\
Lakes $>501$ ha (p-a) & L $>501$ ha
\end{tabular}

Variables measured in the field:

Lake or river riparian sedge and grass $(\mathrm{p}-\mathrm{a}) \quad \mathrm{L} / \mathrm{R}$ grass Lake or river aquatic vegetation $^{4}(\mathrm{p}-\mathrm{a}) \quad \mathrm{L} / \mathrm{R}$ aqua. Lake or river shrubs (p-a) Pond riparian sedge and grass (p-a) Pond aquatic vegetation $^{4}(\mathrm{p}-\mathrm{a})$ Number of bogs or fens with ponds

L/R shrubs Pond grass Pond aqua. Bog/Fen
${ }^{1}$ A $1 \mathrm{~km}$ section of river equals $2 \mathrm{~km}$ of river banks.

${ }^{2}$ Isolated ponds visible on 1:50 000 maps.

${ }^{3} \mathrm{p}-\mathrm{a}=$ presence or absence.

${ }^{4}$ Emerged, submerged and floating-leaved plants.

Vegetation variables were measured in each cell on the basis of a field survey by helicopter in the 55 plots, from 18 August to 14 September 1989. Areas covered by riparian vegetation (shrubs, sedge and grass), aquatic vegetation (emerged, floating and submerged), and bogs and fens with open water were delineated on 1:50 000 maps. In each cell, we counted the number of bogs and fens with pools and classified all other vegetation variables as present or absent (Table 1). 


\section{Statistical Analyses}

Logistic Regression Models: Half of the cells of the 55 $100 \mathrm{~km}^{2}$ plots surveyed in 1989 were used to build the models. They were dispersed in a systematic way (i.e., black cases of a chess board) to optimize independence between cells. Waterfowl use within each of the $27501 \mathrm{~km}^{2}$ cells was coded, by species, as brood presence or absence, and the results of the two survey periods were pooled. Ten cells had missing data, yielding a sample size of 2740. We ran logistic regression (Hosmer and Lemeshow, 1989) on the twelve variables describing the cells (Table 1) to produce models linking species presence and habitat variables. Logistic regression analysis selected habitat variables in a stepwise manner and generated models that estimate the probability of waterfowl presence in $1 \mathrm{~km}^{2}$ cells. For each species, we calculated a cut point by dividing the number of cells in which we observed a brood during the 1989 surveys by the total number of cells used for modelling (2740). If a model generated a probability of presence in a cell greater than the cut point, the prediction of presence of the species in the cell was accepted.

Model Efficiency: Observed and predicted responses (presence or absence of a brood) were computed in a classification table. We tested the null hypothesis of independence between observed and predicted responses (likelihood ratio $\chi^{2}$ ) and measured the correctness of classification and the sensitivity of the models. Correctness is the proportion of well-predicted presences plus well-predicted absences on the total number of cells. Sensitivity is the proportion of cells with waterfowl presence that were predicted to have waterfowl presence (SAS Institute, 1990). This was done with data that were used to build models ( $\mathrm{n}=2740$ cells). As this produces biased results (Diefenbach and Owen, 1989), we repeated the same process with two "validation data sets." The first consisted of data of cells surveyed in 1989 but not used to generate models (i.e., white cases of the chess board; $n=2740$ ). The second set was made of cells (white cases) surveyed in $1990(n=890)$ to optimize independence.

Wetland Use Comparisons: For each species, we noted the number of broods observed on different water bodies for the three surveys. For lakes $\leq 10$ ha, we also examined frequency distributions of broods relative to vegetation characteristics. Wetland use was then compared between species ( $G$ tests and Simultaneous Test Procedure; Sokal and Rohlf, 1981). When a significant difference was encountered, a goodness-of-fit test $\left(\chi^{2}\right)$ (Scherrer, 1984) was used to identify, for each wetland category, the differences in species use. In all analyses, the level of significance was set to 0.05 .

\section{RESULTS}

During the first 1989 survey, a plot was censused in an average of $76.2 \mathrm{~min}$, compared to $116.1 \mathrm{~min}$ during the second survey and $181.3 \mathrm{~min}$ in 1990 . The first survey in 1989 was during the peak of hatching for all species except scaups, which had their peak at the end of the survey period and later
(Fig. 2). The second survey was performed when hatching was almost over for all species. In 1990, waterfowl were surveyed after the peak of hatching, except again for scaups. In 1989 , brood densities per $100 \mathrm{~km}^{2}$ were $2.0(\mathrm{SE}=0.4)$ for green-winged teal, $1.3(\mathrm{SE}=0.2)$ for black scoter, 2.3 $(\mathrm{SE}=0.4)$ for surf scoter, and $2.1(\mathrm{SE}=0.4)$ for scaups.

\section{Logistic Models}

In the $27401 \mathrm{~km}^{2}$ cells used for modelling, 51 cells $(1.86 \%)$ contained broods of green-winged teal against 61 (2.23\%) of black scoter, 56 (2.04\%) of surf scoter and 41 (1.50\%) of scaups.

Green-winged teals were associated with ponds, bogs or fens and shrubs bordering lakes, but they avoided large lakes (> 501 ha) (Table 2). Black and surf scoters' broods were correlated with the number of small lakes $(<10$ ha) and the presence of lakes 10-100 ha (Table 2). Black scoters were also correlated with ponds and with lakes with sedge and grass, whereas surf scoters were not. Scaup broods were associated with aquatic vegetation: the variables $\mathrm{L}<10$ ha, $\mathrm{L} 10-100 \mathrm{ha}$ and $\mathrm{L} / \mathrm{R}$ grass were significant until the aquatic vegetation variable entered the model.

TABLE 2. Logistic regression models for waterfowl presence based on habitat variables.

\begin{tabular}{|c|c|c|c|}
\hline Selected habitat variable ${ }^{1}$ & Parameter estimate & Wald $\chi^{2}$ & $p>\chi^{2}$ \\
\hline \multicolumn{4}{|c|}{ Green-winged teal $\left(-2 \log L=453.21, \chi^{2}=54.19, \mathrm{df}=4, p=0.0001\right)$} \\
\hline Intercept & -4.416 & 419.32 & 0.0001 \\
\hline Ponds & 0.211 & 33.87 & 0.0001 \\
\hline L/R shrubs & 1.211 & 6.00 & 0.0143 \\
\hline $\mathrm{L}>501$ ha & -1.232 & 5.48 & 0.0192 \\
\hline Bog/Fen & 0.230 & 4.70 & 0.0302 \\
\hline \multicolumn{4}{|c|}{ Black scoter $\left(-2 \log \mathrm{L}=550.06, \chi^{2}=34.77, \mathrm{df}=4, p=0.0001\right)$} \\
\hline Intercept & -4.789 & 338.08 & 0.0001 \\
\hline $\mathrm{L}<10$ ha & 0.189 & 10.42 & 0.0012 \\
\hline L $10-100$ ha & 0.831 & 8.58 & 0.0034 \\
\hline $\mathrm{L} / \mathrm{R}$ grass & 0.791 & 5.95 & 0.0147 \\
\hline Ponds & 0.093 & 5.24 & 0.0220 \\
\hline \multicolumn{4}{|c|}{ Surf scoter $\left(-2 \log L=527.13, \chi^{2}=19.44, \mathrm{df}=2, p=0.0001\right)$} \\
\hline Intercept & -4.674 & 314.95 & 0.0001 \\
\hline L $10-100$ ha & 0.962 & 10.65 & 0.0011 \\
\hline $\mathrm{L}<10$ ha & 0.162 & 6.72 & 0.0096 \\
\hline \multicolumn{4}{|c|}{ Scaup $\left(-2 \log \mathrm{L}=404.91, \chi^{2}=21.05, \mathrm{df}=1, p=0.0001\right)$} \\
\hline Intercept & -4.820 & 368.79 & 0.0001 \\
\hline $\mathrm{L} / \mathrm{R}$ aqua & 1.467 & 20.61 & 0.0001 \\
\hline
\end{tabular}

\footnotetext{
${ }^{1}$ See Table 1 for descriptions of variables.
}

Except for scaups in the second validation data set, predicted values fit the data (Table 3). Models generally gained sensitivity when applied to the validation data sets, whereas their correctness tended to decrease (Table 3 ).

\section{Wetland Use Comparisons}

The use of water bodies differed between all species $(\mathrm{G}=$ $197.8, \mathrm{df}=12, p \leq 0.01)$ except surf scoters and scaups 
TABLE 3. Sensitivity, correctness and independence of the data in the logistic regression models.

\begin{tabular}{|c|c|c|c|c|c|}
\hline Species & $\begin{array}{l}\text { Cut } \\
\text { point }\end{array}$ & Sensitivity $^{1}$ & Correctness $^{2} \mathrm{I}$ & $\begin{array}{l}\text { Likelihood }^{3} \\
\text { ratio } \chi^{2}\end{array}$ & Probability \\
\hline \multicolumn{6}{|c|}{ Data used to generate the model ( 1989 survey; $n=2740$ cells $)$} \\
\hline Green-winged teal & 0.0186 & 0.53 & 0.77 & 21.38 & $<0.001$ \\
\hline Black scoter & 0.0223 & 0.67 & 0.64 & 23.30 & $<0.001$ \\
\hline Surf scoter & 0.0204 & 0.70 & 0.53 & 11.43 & 0.001 \\
\hline Scaup spp. & 0.0149 & 0.61 & 0.73 & 21.05 & $<0.001$ \\
\hline \multicolumn{6}{|c|}{ First set of validation data (1989 survey; $\mathrm{n}=2740$ cells $)$} \\
\hline Green-winged teal & & 0.73 & 0.61 & 34.43 & $<0.001$ \\
\hline Black scoter & & 0.69 & 0.63 & 30.12 & $<0.001$ \\
\hline Surf scoter & & 0.67 & 0.53 & 7.98 & 0.005 \\
\hline Scaup spp. & & 0.64 & 0.72 & 23.16 & $<0.001$ \\
\hline \multicolumn{6}{|c|}{ Second set of validation data (1990 survey; $\mathrm{n}=890$ cells) } \\
\hline Green-winged teal & & 0.82 & 0.50 & 8.80 & 0.003 \\
\hline Black scoter & & 0.83 & 0.60 & 4.66 & 0.031 \\
\hline Surf scoter & & 0.79 & 0.53 & 7.75 & 0.005 \\
\hline Scaup spp. & & 0.52 & 0.65 & 2.70 & 0.101 \\
\hline
\end{tabular}

${ }^{1}$ Sensitivity is the proportion of presences that were predicted to be a presence.

${ }^{2}$ Correctness is the proportion of well-predicted presences plus well-predicted absences in the total number of cells.

${ }^{3}$ Tests the null hypothesis of independence between observed and predicted responses.

$(\mathrm{G}=5.2, \mathrm{df}=4, p=0.27)$ (Fig. 3). Scaups and green-winged teals used lakes $<10$ ha with the same vegetation characteristics $(\mathrm{G}=4.4$, $\mathrm{df}=3, p=0.218)$, as did the two scoters $(\mathrm{G}<0.1, \mathrm{df}=3, p=0.996)$.

Green-winged teal used fens and bogs significantly more than the other species $\left(\chi^{2}=119.9, \mathrm{df}=1, p<0.0001\right)$ (Fig. 3). Teals also used lakes $<10 \mathrm{ha}\left(\chi^{2}=8.3, \mathrm{df}=1, p=0.004\right)$ and lakes $10-100$ ha $\left(\chi^{2}=40.3, \mathrm{df}=1, p<0.0001\right)$ significantly less than the other species. Differences in wetland use by black and surf scoters were detected $(\mathrm{G}=19.3, \mathrm{df}=4, p=$ $0.001)$. Surf scoter broods were observed almost exclusively on small and medium lakes ( $87.8 \%$ of all observations), whereas black scoters also used ponds (Fig. 2). Black scoters used this wetland type significantly more than surf scoters $\left(\chi^{2}=10.7\right.$, $\mathrm{df}=1, p<0.0001)$. Black scoters used lakes $10-100$ ha significantly less than surf scoters $\left(\chi^{2}=5.4, \mathrm{df}=1, p=0.0201\right)$.

Scaup and surf scoter broods used small and medium sized lakes. However, scaups and green-winged teals used lakes $<10$ ha with aquatic vegetation $\left(\chi^{2}=7.3, \mathrm{df}=1, p=0.008\right)$ or aquatic and riparian vegetation $\left(\chi^{2}=16.3\right.$, df $=1$, $p<0.0001)$ more than the black and surf scoters, which were observed more often on lakes with no vegetation $\left(\chi^{2}=16.4\right.$, $\mathrm{df}=1, p<0.0001)($ Fig. 3).

\section{DISCUSSION}

We used logistic regression analysis because it is a better tool than discriminant function analysis or linear regression for modelling data that can deviate from multivariate normal-
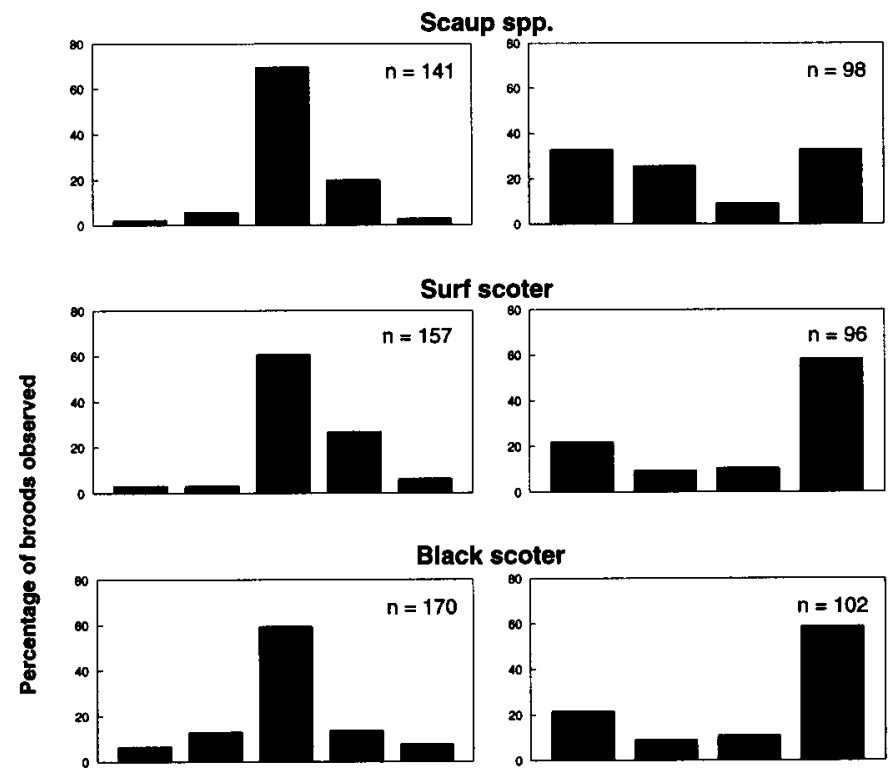

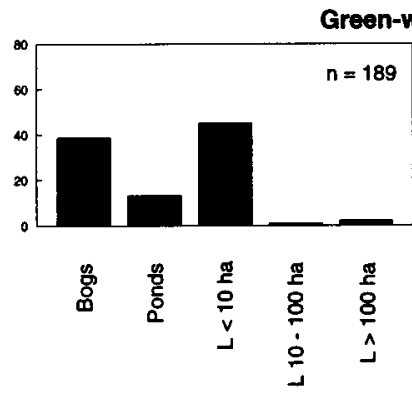

Water body

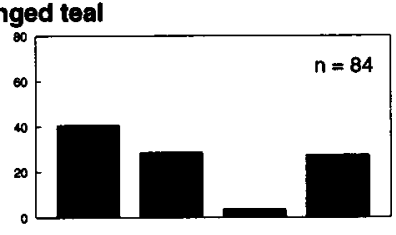

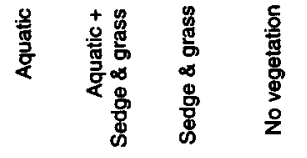
on lakes $<10 \mathrm{ha}$
Vegetation

FIG. 3. Percentage of broods observed on different water bodies and on lakes $<10$ ha with different vegetation cover in the 55 plots surveyed in 1989 and 1990.

ity and equal covariation (Efron, 1975; Press and Wilson, 1978; Brennan et al., 1986; Trexler and Travis, 1993). Logistic regression is designed for binary outcome variables such as those studied here (Hosmer and Lemeshow, 1989). All four models fit the data and showed sensitivity and correctness. They lost correctness but gained sensitivity when applied to the validation data sets. The weakness of the model for scaups in the second year is probably due to the bad timing of the survey with respect to breeding chronology. Decrease in correctness during validation indicates that models predicted presence of waterfowl in a higher number of empty cells. This weakness in the predictive power of the models is probably due to methodological and ecological factors.

We chose one of every two $1 \mathrm{~km}^{2}$ cells from the 55 plots in a systematic fashion as the units for modelling to improve independence between units. Habitat patchiness at the plot scale in the study area also increased the independence between cells. Cells of $1 \mathrm{~km}^{2}$ were considered large enough to optimize the range of values for some hydrographic characteristics, such as the number of ponds and small lakes (Porter and Church, 1987). We also assumed the cells would be representative of average home ranges of waterfowl broods 
in subarctic regions, although information is lacking on movements of broods and home range sizes of many species breeding in these regions (Bengtson, 1971; Bellrose, 1980). A better understanding of these parameters could permit optimization of the size and shape of cells that would enhance predictive efficiencies of logistic models.

Modelling with the two surveys in 1989 compensated for the imperfection in survey timing according to hatching chronology. However, more surveys would have given a better image of brood movements and habitat use through the season. Diefenbach and Owen (1989) reported that it took them four visits in the same year before they stopped finding new wetlands with black ducks. Because the 1989 surveys were spread over a long period, an undetermined portion of the broods could have been missed because the brood had not hatched before the first survey or had died before the second one. The first possibility certainly occurred for all species, since broods were still hatching when the first survey started. Despite the suitability of a brood-rearing habitat, nest failure, which can be important (Greenwood et al., 1995), predation, or other biotic phenomena which we did not measure could have resulted in the absence of broods. Moreover, some green-winged teal broods were capable of flight at the early stage of the second survey and could have moved from their breeding area. On the other hand, scoters and scaup broods were not able to fly until after the second survey.

Undetected broods could affect the accuracy of the models, although in our study area we suspect that our survey technique and the openness of habitats resulted in less error due to lack of detection than in other surveyed regions (Haapanen and Nilsson, 1979; Martin et al., 1979; Goudie and Whitman, 1987; Bordage, 1988). Low tree height, which permitted observers to fly at low altitude safely, aided waterfowl detection.

Low predictability may characterize regions where brood densities are so low that not all primary habitats are used. In our study area, broods were present in only a small percentage of cells. The density of lakes $<10$ ha, a wetland type used by all species in this study, is 55 times the density of broods of surf scoter, the most abundant species. Model precision could be improved by using abiotic factors not measured here (water depth, type of substrate, extreme weather, $\mathrm{pH}$; DesGranges and Houde, 1989), provided that those factors correlate with waterfowl presence and that measuring them is more cost-effective than measuring waterfowl use of habitats itself.

In some waterfowl species, most individuals may behave opportunistically (Rosenzweig, 1985:518), using habitats as they are encountered during brood-rearing. For such species, high predictive values are less likely. In spite of these limitations, we believe that the models are robust.

Results of the logistic regression are consistent with what is known of habitat use by green-winged teals in northern regions. In the Northwest Territories, Toft et al. (1982) found green-winged teal broods using small wetlands and avoiding large and medium-sized ones. In our study area, the small and vegetated wetlands mostly used by teals were parts of fens and bogs with shallow water. The variable "ponds" was related to the variable "bog/fen" (Mantel-Haenszel $\chi^{2}=104.8, \mathrm{df}=1$, $p<0.0001$ ). In Labrador, Goudie and Whitman (1987) found dabbling ducks in peatlands. In northern Fennoscandia, mire complexes, as well as woodland regions, harbored the highest densities of breeding green-winged teals (Haapanen and Nilsson, 1979). Shallow areas of water bodies with riparian and aquatic vegetation were preferred by European greenwinged teals as sites for feeding (Pöysä, 1983) and loafing (Bengtson, 1971).

In northern Scotland and south of Ungava Bay, Québec, black scoters were associated with lakes with islands and with vegetated, productive, and nonacidic lakes (Fox et al., 1989; DesGranges and Houde, 1989). In northern Fennoscandia, the highest densities of black scoters occurred in the mountain range at all altitudes and in woodland regions (Haapanen and Nilsson, 1979). The surf scoter breeds exclusively in North America. Its habitat preferences during brood-rearing are generally considered similar to those of black scoter (Bellrose, 1980), but comparative studies are lacking. Goudie and Whitman (1987) and Savard and Lamothe (1991) did not differentiate the two species and found scoters on lakes with rocky shores and little or no emergent cover. Our results suggest that differences in habitat use by black and surf scoters may exist during brood-rearing. The variable "ponds" is strongly associated with bogs and fens, which suggests that this wetland type could be used more by black scoters than by surf scoters. Sedge and grass bordering lakes, as shown in the models, seem important for black scoters and of limited value for surf scoters (probability of $\chi^{2}$ to be included in the model at the last step $=0.72$ ). This seems to contradict the similarities observed between the two species in the frequency distributions of vegetation type use on lakes $<10$ ha. However, logistic regression takes into account the availability of habitat, whereas the frequency distribution analysis does not. Finally, black scoters use medium-sized lakes (10100 ha) less than surf scoters do. Further investigations of wetland and lake characteristics and their use by sympatric surf and black scoter broods may provide a better understanding of the differences that seem to exist in their brood-rearing habitat preferences.

The results of the model and of wetland use comparisons indicate that scaup broods may be found on any lake, provided it is vegetated and not too large ( $<100$ ha). In Alaska and the Northwest Territories, scaup broods were mostly sighted on large ponds with grassy shores (Derksen et al., 1981; Toft et al., 1982). In Fennoscandia, scaups were mostly found in productive and vegetated water bodies (Haapanen and Nilsson, 1979).

Our study is the most precise attempt to date to model large-scale relationships between these waterfowl species and habitat parameters in northern boreal Québec. As predictive tools, the models could be improved with a careful selection of sample-cell size and frequent surveys repeated during the breeding period. The addition of some habitat parameters, provided these are easily and cheaply obtainable, could also enhance the models' accuracy. These tools could become useful for screening to identify zones with good waterfowl potential in remote areas where surveying is expensive. 


\section{ACKNOWLEDGEMENTS}

This study was part of the Grande-Baleine hydroelectric project studies undertaken by Hydro-Québec (Montréal). We wish to thank Daniel Bordage of Canadian Wildlife Service (Québec) for sharing his experience and survey techniques, and for reviewing an earlier draft. We also thank Bruno Scherrer (Jouveinal Inc., France) for his valuable advice on statistics. Dominique Arseneault and Alain Gouge greatly contributed to fieldwork, and we appreciate the meticulous work by G.R.E.B.E. staff in collecting and verifying data. J.-F. Giroux, P. Lamothe, M. Laperle, Y. Leblanc, A. Reed, J.-F. Rougerie, M. Saint-Georges, R.D. Titman and four anonymous referees kindly reviewed the manuscript.

\section{REFERENCES}

AD HOC SEA DUCK COMMITTEE. 1993. Status of sea ducks in the Atlantic flyway with strategies towards improved management. Atlantic Flyway Technical Section, U.S. Fish and Wildlife Service.

BELLROSE, F.C. 1980. Ducks, geese and swans of North America. Third edition. Harrisburg, Pennsylvania: Stackpole Books.

BENGTSON, S.-A. 1971. Habitat selection of duck broods in Lake Myvatn area, north-east Iceland. Ornis Scandinavica 2:17-26.

BIDER, R., and LAMOTHE, P. 1982. Synthèse des études sur les populations de canards menées entre les années 1975 et 1980 dans les bassins de la Grande rivière de la Baleine et de la Petite rivière de la Baleine. Unpubl. ms. Available at Hydro-Québec, Vice-présidence Ingénierie et services, 800 est de Maisonneuve, Montréal, Québec H2L 2G3, Canada.

BORDAGE, D. 1988. Suivi des couples nicheurs de canard noir en forêt boréale, 1987. Série de rapports techniques no 35. Service canadien de la faune, région du Québec, 1141 route de l'Église, C.P. 10100, Ste Foy, Québec G1V 4H5, Canada.

BRENNAN, L.A., BLOCK, W.M., and GUTIERREZ, R.J. 1986. The use of multivariate statistics for developing habitat suitability index models. In: Verner, J., Morrison, M.L., and Ralph, C.J., eds. Wildlife 2000: Modelling habitat relationships of terrestrial vertebrates. Madison, Wisconsin: University of Wisconsin Press. $177-182$.

COCHRAN, W.G. 1977. Sampling techniques. Third edition. New York: Wiley.

CONSORTIUM GAUTHIER \& GUILLEMETTE - G.R.E.B.E. 1990. Complexe Grande-Baleine. Avant-projet Phase II. Étude de l'avifaune et du castor: Écologie de la sauvagine (été 1989). Unpubl. ms. Available at Hydro-Québec, Vice-présidence Ingénierie et services, 800 est de Maisonneuve, Montréal, Québec H2L 2G3, Canada.

DERKSEN, D.V., ROTHE, T.C., and ELDRIDGE, W.D. 1981. Use of wetland habitats by birds in the National Petroleum Reserve-Alaska. Washington, D.C.: U.S. Fish and Wildlife Service. Resource Publication No. 141.

DESGRANGES, J.-L., and HOUDE, B. 1989. Influence de l'acidité et d'autres paramètres environnementaux sur la distribution des oiseaux lacustres au Québec. In: DesGranges, J.-L., ed. Étude des effets de l'acidification sur la faune aquatique au Canada:
Les oiseaux lacustres et leurs habitats au Québec. Service canadien de la Faune. Publication hors série n $67.7-44$.

DIEFENBACH, D.R., and OWEN, R.B. 1989. A model of habitat use by breeding American black ducks. Journal of Wildlife Management 53(2):383-389.

EFRON, B. 1975. The efficiency of logistic regression compared to normal discriminant analysis. Journal of the American Statistical Association 70:892-898.

FOX, A.D., JARRETT, N., GITAY, H., and PAYNTER, D. 1989. Late summer habitat selection by breeding waterfowl in northern Scotland. Wildfowl 40:106-114.

GILLESPIE, D., and WETMORE, S.P. 1974. Waterfowl survey in Labrador-Ungava, 1970, 1971, 1972. In: Boyd, H., ed. Waterfowl studies in eastern Canada, 1969-1973. Canadian Wildlife Service Report Series 29. 8-18.

GOLLOP, J.P., and MARSHALL, W.H. 1954. A guide for aging duck broods in the field. Mississipi Flyway Council Technical Section.

GOUDIE, R.I., and WHITMAN, W.R. 1987. Waterfowl populations in Labrador, 1980-82. In: Erskine, A.J., ed. Waterfowl breeding populations surveys. Atlantic provinces. Canadian Wildlife Service. Occasional Paper No. 60.

GREENWOOD, J., SARGEANT, A.B., JOHNSON, D.H., COWARDIN, L.M., and SHAFFER, T.L. 1995. Factors associated with duck nest success in the prairie pothole region of Canada. Wildlife Monographs No. 128.

HAAPANEN, A., and NILSSON, L. 1979. Breeding waterfowl populations in northern Fennoscandia. Ornis Scandinavica 10:145-219.

HOSMER, D.W., Jr., and LEMESHOW, S. 1989. Applied logistic regression. New York: John Wiley \& Sons.

JOHNSON, D.H., and GRIER, J.W. 1988. Determinants of breeding distributions of ducks. Wildlife Monographs No. 100. 37 p.

KACZYNSKI, C.F., and CHAMBERLAIN, E.B. 1968. Aerial surveys of Canada geese and black ducks in eastern Canada. Washington, D.C.: U.S. Fish and Wildlife Service Special Scientific Report, Wildlife No. 118.

MALECKI, R.A., and TROST, R.E. 1990. A breeding ground survey of Atlantic Flyway Canada geese, Branta canadensis, in northern Québec. Canadian Field-Naturalist 104:575-578.

MARTIN, F.W., POSPAHALA, R.S., and NICHOLS, J.D. 1979. Assessment and population management of North American migratory birds. In: Cairns, J., Jr., Patil, G.P., and Waters, W.E., eds. Environmental biomonitoring, assessment, prediction, and management-Certain case studies and related quantitative issues. Statistical Ecology, Vol. 11. Fairland, Maryland: International Cooperative Publishing House. 187-239.

PALMER, R.S. 1976. Handbook of North American Birds. Volumes 2 and 3. New Haven: Yale University Press.

PAYETTE, S. 1983. The forest tundra and present tree-line of the northern Québec-Labrador peninsula. In: Morisset P., and Payette, S., eds. Tree-line ecology. Proceedings of the Northern Québec Tree-Line Conference. Nordicana 47:3-23.

PORTER, W.F., and CHURCH, K.E. 1987. Effects of environmental pattern on habitat preference analysis. Journal of Wildlife Management 51:681-685.

PÖYSÄ, H. 1983. Resource utilization pattern and guild structure in a waterfowl community. Oikos 40:295-307. 
PRESS, S.J., and WILSON, S. 1978. Choosing between logistic regression and discriminant analysis. Journal of the American Statistical Association 73:699-705.

REYNOLDS, R.E. 1987. Breeding duck population, production and habitat surveys, 1979-85. Transactions of the North American Wildlife and Natural Resources Conference 52:186205.

ROSENZWEIG, M.L. 1985. Some theoretical aspects of habitat selection. In: Cody, M.L., ed. Habitat selection in birds. San Diego: Academic Press, Inc. 517-540.

SAS INSTITUTE. 1990. SAS/STAT User's Guide, Version 6, Fourth edition, Vol. 2. Cary, North Carolina: SAS Institute Inc.
SAVARD, J.-P., and LAMOTHE, P. 1991. Distribution, abundance, and aspects of breeding ecology of black scoters, Melanitta nigra, and surf scoters, M. perspicillata, in Northern Québec. Canadian Field-Naturalist 105(4):488-496.

SCHERRER, B. 1984. Biostatistique. Chicoutimi, Québec: G. Morin editeur.

SOKAL, R.R., and ROHLF, F.J. 1981. Biometry. Second edition. New York: W.H. Freeman and Co.

TOFT, C.A., TRAUGER, D.L., and MURDY, H.W. 1982. Tests for species interactions: Breeding phenology and habitat use in subarctic ducks. American Naturalist 120:589-613.

TREXLER, J.C., and TRAVIS, J. 1993. Nontraditional regression analysis. Ecology 74(6):1629-1637. 